\title{
Necessidades, Apoio e Proteção Sociais
}

A discussão do apoio social é oportuna. Remete a propostas complementares de políticas de proteção social, atenuadoras das desigualdades sociais e ao debate de novas e antigas necessidades sociais e de saúde da população. Exemplos podem ser citados de demandas sociais como os dependentes de drogas ilícitas, entre elas o crack, que aguardam políticas sociais integradas, intersetoriais e assistência humanizada nas instituições sociais e de saúde. Parcela de jovens, adolescentes e adultos habitam os redutos urbanos, como nômades expostos ao abandono social.

O envelhecimento da população, na transição epidemiológica, pesa na expansão das enfermidades crônicas não transmissíveis e das incapacidades consequentes acentuando a vulnerabilidade social dos idosos isolados ou dos inseridos nas famílias empobrecidas, demandantes de cuidados especiais. Os idosos conquistaram no seu Estatuto maior cidadania formal e maior cobertura dos serviços da rede básica de serviços de saúde do Sistema Único de Saúde. Similarmente perde força a visão filantrópica e caritativa em função dos direitos sociais e cidadania, após a conquista do Estatuto das Crianças e dos Adolescentes no Brasil.

A família é núcleo social tradicional de prestações sociais, permeando as obrigações e os deveres entre seus membros. Funciona como apoio informal na condição de pobreza. Dela se demandou cuidados complementares aos oferecidos pelas instituições médicas para idosos, crianças, incapacitados e deficientes; a transferência de tecnologias para o domicílio, como da hemodiálise para os portadores de insuficiência renal crônica. Argumenta-se o atendimento mais humanizado no seio da família do que no hospital. Pouco tem sido investigado sobre estes encargos familiares.

São diversas as condições de vulnerabilidade social e pobreza. A política de apoio social quer estimular as relações e os vínculos sociais e fortalecer o tecido social. Contrapõe-se à sua fragilização e individualização diante das mudanças estruturais da produção, nas relações interpessoais e de poder na sociedade moderna. As estratégias e o conceito de apoio social devem superar a sua visão como recurso, instrumento e objeto neutro, deslocado das políticas de proteção social, da compreensão das relações sociais e de poder, das desigualdades sociais e da dinâmica dos processos sociais pelos quais passam a sociedade e o seu sentido para os diferentes grupos sociais.

Ana Maria Canesqui

Editora convidada 